\title{
"POLITICAL" BLACKLISTING IN THE MOTION PICTURE INDUSTRY: A SHERMAN ACT VIOLATION
}

Following an investigation of Hollywood, begun in 1947 by the House Committee on Un-American Activities to determine the prevalence of Communism in the motion picture industry, ${ }^{1}$ eight writers, a writer-producer, and a director, later known as the "Unfriendly Ten" or "Hollywood Ten," were convicted of contempt of Congress for refusing to testify.2 In the fall of 1947, members of the Motion Picture Association of America, the Association of Motion Picture Producers, and the Society of Independent Motion Picture Producers met in the Waldorf-Astoria in New York City, and publicly pledged that the industry would refuse to hire "subversives." Several motion picture executives initially opposed this "Waldorf Declaration," but ultimately succumbed to pressures from Eric Johnston, president of the Association of Motion Picture Producers, and others present at the meeting. ${ }^{4}$ As a result of this declaration, the Hollywood blacklist developed, eventually expanding to include not only those involved in the congressional investigations, but also those whose activities were deemed subversive by the industry. ${ }^{\circ}$ Despite the

1. Hearings before the House Conmmittee on Un-American Activilies on Communist Infiltration of the Motion-Picture Industry in the United States, 80th Cong, 1st Sess. (1947). 1 COGLEY, REPORT ON BLACKLISTING 1-24 (1956).

2. Lawson v. United States, 176 F.2d 49, 50 (D.C. Cir. 1949), cert. denied, 339 U.S. 934 (1950).

3. This pledge, known as the "Waldorf Declaration," says in part:

We will forthwith discharge or suspend without compensation those in our employ and we will not re-employ any of the 10 until such time as he ... has purged himself of contempt and declares under oath that he is not a Communist.

We will not knowingly employ a Communist or a member of any party or group which advocates the overthrow of the government of the United States by force or by any illegal or unconstitutional methods ...

N.Y. Times, Nov. 26, 1947, p. 27, col. 2. See also 1 Coglex, Report on Blacristnic 22-23 (1956) for complete text.

4. Cole v. Loew's, Inc., 8 F.R.D. 508, 524 (S.D. Cal. 1948); 1 CogLEY, Repost o:: BLACKLISTING 17 (1956).

5. See generally 1 Cogley, Report on Blackistmic (1956); Schunsacr, The Face on tHe Cutring RooMr Floor 122 (1964). The story of Louis Pollock, once a successful Hollywood writer, illustrates how the blacklist operated. Because of a similarity in names, Pollock was mistaken for a clothier who had refused to testify before HUAC. He was blacklisted and the producers uniformly refused to accept his scripts. Since he was unable to ascertain the reason why his scripts were rejected, he could not clear himself, and thus was forced out of the industry. Id. at 122-23. See Washington Post, Aug. 25, 1964, cditorial page, col. 2 ; N.Y. Times, Aug. 25, 1964, p. 33, cols. 2 \& 3.

The industry-wide boycott was extended in 1952 to the Independent Productions Corp. formed in part by some of the "blacklistees." That corporation alleged that the motion picture industry had interfered with the production, distribution, and exhibition of its film 
continued insistence by members of the industry that there has been no concerted effort to maintain a uniform list, the similarity between the lists maintained by each studio has led one commentator to the conclusion that they could "have been produced on a single mimeograph machine." Since the major film companies control the distribution of not only their own films, but also the films of independent producers, ${ }^{7}$ the blacklist, as an outgrowth of the Waldorf Declaration, exacts conformity of conduct among the producers, and effectively bars the listed actors and writers from the entire motion picture industry. In the eighteen years since the Waldorf Declaration several legal attempts have "Salt of the Earth." Independent Productions Corp. v. Loew's, Inc, 22 F.R.D. 266 (S.D. N.Y. 1958).

In June, 1960, each of the producers entered agreements with the Screen Writers' Guild under which a writer could be denied credit only if the producer was unaware of the writer's blacklisted status: these agreements had the effect of terminating the black markct through which the blacklisted writers had previously sold their scripts. On November 4, 1960 Eric Johnston re-enunciated "the policy of the MPAA member companics in regard to the hiring of Communists in the creation of motion pictures," emphasizing that the MPAA member companies were to "ask their associates to adhere to this policy." Sco Brief for Appellants, pp. 9-11, and Reply Brief for Appellants, pp. 6-7, Young v. Motion Picture Ass'n of America, Inc., 299 F.2d 119 (D.C. Cir. 1962).

6. Schuncach, The Face on the Cutring Room Floor 120 (1964). The troublesome question of what constitutes sufficient proof of an antitrust conspiracy, or group action amounting to a boycott, is beyond the scope of this Note. For discussions of this problem, see Delaware Valley Marine Supply Co. v. American Tobacco Co., 297 F.2d 199 (3d Cir. 1961); Turner, The Definition of Agreement under the Sherman Act: Conscions Parallelism and Refusals to Deal, 75 Harv. L. Rev. 655 (1962); Conant, Consciously Parallel Action in Restraint of Trade, 38 MrNo. L. REv. 797 (1954); Rahl, Conspiracy and the Anti-Trust Lazes, 44 Irl. L. Rev. 743 (1950); Atrorney General Nat'l CoMM. ANTrtrust REp. 30-42 (1955). But it seems clear that in the "Hollywood Ten" situation the evidence would support a finding of conspiracy and combination.

7. The motion picture industry consists of three distinct divisions - production, distribution, and exhibition. Films are produced by eight major concerns - Columbia, Metro-Goldwyn-Mayer, Paramount, RKO Radio (presently inactive), Twenticth CenturyFox, United Artists, Universal, and Warner Brothers - and by a large number of independent producers. Since these eight concerns own or control their own distribution facilities and control nearly all of the nation-wide distributing facilities, the independent producers' access to the exhibitors must be through the major concerns. Distributionfinancing agreements are generally made in advance of production, and contain certain "employment controls" which give the major concerns complete veto power over the independents' hiring policies. The Motion Picture Association has admitted that such 'controls" exist and has defended them as necessary to protect the companies' investments. Brief for Appellants, p. 4 n.7, Young v. Motion Picture Ass'n, Inc., 299 F.2d 119 (D.C. Cir. 1962). See also Cassady, Impact of the Paramount Decision on Motion Pichure Distribution and Price Making, 31 So. CAL. L. Rev. 150 (1958).

Today, none of the "blacklistees" can be hired by any of the major movic conccrns except United Artists. Nor, except in the rare case of an independent producer as powerful as Otto Preminger, can any independent hire without being subject to veto by the largo producer-distributors. Interview with Counsel for Plaintiffs, Young v. Motion Picturc Ass'n, Washington, D.C., March 30,1964. "[T]he blacklist . . . is very much alive in 1964 ...." Schunach, The Face on the Cutring Room Floor 129 (1964). 
been made to avoid the effect of the blacklist, ${ }^{8}$ but only one case ${ }^{0}$ has squarely challenged its legality as a group boycott under the Sherman Act. ${ }^{10}$

In Young v. Motion Picture Association of Amcrica, Inc., ${ }^{11}$ plaintiffs, some of whom were among the original Hollywood Ten, filed suit in the United States District Court for the District of Columbia alleging that the Waldorf Declaration and the ensuing refusal to hire constitute a combination and conspiracy in restraint of trade and in violation of the Sherman Act. Although the case has been heard several times on procedural questions, the merits of plaintiff's contention have not yet been reached.12 Defendants, however, have joined issue on the merits in their answer. They contend that even assuming a concerted refusal to hire, such a refusal does not come within the scope of the Sherman Act ban on group boycotts, as defined most recently by the Supreme Court in Fashion Originators' Guild of America, Inc. v. FTC,13 and Klor's, Inc. $v$. Broadway-Hale Stores, Inc. ${ }^{14}$ In the alternative, the producers argue that a boycott otherwise within the scope of the Sherman Act may be legal when directed to the achievement of valid social, moral, and political goals. ${ }^{10}$

In Fashion Originators' Guild ${ }^{10}$ the Court held illegal a refusal by manufacturers to sell to retailers who dealt in garments manufactured by "style pirates." Justice Black, speaking for a unanimous Court, stated that:

8. See, e.g., Scott v. RKO Radio Pictures, Inc., 240 F.2d 87 (9th Cir.), cert. denisd, 353 U.S. 939 (1957); Twentieth Century-Fox Film Corp. v. Lardner, 216 F.2d 844 (9th Cir. 1954), cert. dentied, 348 U.S. 944 (1955); Cole v. Loev's, Inc, 8 F.R.D. 503 (S.D. Cal. 1948), rez'd, 185 F.2d 641 (9th Cir. 1950); RKO Radio Pictures, Inc. v. Jarrico, 128 Cal. App. 2d 172, 274 P.2d 928 (1954), cert. denied, 349 U.S. 928 (1955) (all actions for breach of contract); Wilson v. Loew's, Inc. 142 Cay. App. 2d 183, 298 P.2d 152 (Dist. Ct. App. 1956), petition for cert. dismissed, 355 U.S. $59 \%$ (1958) (tort action alleging malicious interference with the pursuit of an occupation by means of the blacklist). In none of these attempts to avoid the effects of the blacklist were the plaintiffs successful; several cases were settled out of court prior to final determination on the merits.

9. Young v. Motion Picture Ass'n, Inc, 299 F.2d 119 (D.C. Cir. 1962).

10. 26 Stat. 209 (1890), as amended, 15 U.S.C. $\$ \$ 1-7$ (1958).

An action alleging that as a result of a conspiracy on the part of the industry, the Hollywood Ten were unemployable, was dismissed by the plaintiffs. MLaltz v. Loew's, Inc., Civil No. 9717 BH, S.D. Cal., May, 1949; see Horowitz, Loyally Tests for Employment in the Motion Picture Industry, 6 Stan. L. Rev. 438, 446-47 (1954). An action brought under the Sherman Act, in which plaintiff corporation alleged a conspiracy to prevent and interfere with the production, distribution, and exhibition of its film, has not yet come to trial. Independent Productions Corp. v. Loew's, Inc, 22 F.R.D. 266 (S.D.N.Y. 1958).

11. 299 F.2d 119 (D.C. Cir. 1962).

12. A motion brought under Rule 30(b) of the Federal Rules of Civil Procedure to preclude inquiry as to the plaintiffs' political associations or beliefs on depositions taken by defendants was denied. 28 F.R.D. 2 (D.D.C. 1961). The denial by the district court of a motion for a preliminary injunction was upheld by the court of appeals, without going into the merits of the cause of action. 299 F.2d 119 (D.C. Cir. 1962).

13. 312 U.S. 457 (1941).

14. 359 U.S. 207 (1959).

15. See Reply Brief for Appellants, pp. 1-2, Young v. Motion Picture Ass'n, Inc., 299 F.2d 119 (D.C. Cir. 1962).

16. 312 U.S. 457 (1941). 
the purpose and object of this combination, its potential power, its tendency to monopoly, the coercion it could and did practice upon a rival method of competition, all brought it within the policy of the prohibition declared by the Sherman and Clayton Acts. ${ }^{17}$

It is not clear, however, whether concerted action alone was the basis for the Court's holding, or whether it was essential to a finding of illegality that the boycott be directed against competitors and productive of monopoly.

It can be argued that the second and narrower reading of Fashion Originators' Guild was endorsed by the Court, again speaking unanimously throtgh Justice Black, in Klor's, Inc. v. Broadway-Hale Stores, Inc.18 In that case, manufacturers of electrical appliances were alleged to have combined with each other and with Broadway-Hale, a retail dealer and competitor of Klor's, to refuse to supply Klor's with appliances. The Court, in holding this an illegal boycott, spoke of the "monopolistic tendency" of the combination, and also referred to "group boycotts, or concerted refusals by traders to deal with other traders." 19 In the context of the opinion, "traders" might be read as meaning "competitors." While these two elements - tendency to monopoly and direction against competitors - may have been present in Fashion Originators Guild and Klor's, and arguably were necessary to a finding of illegality, they are clearly absent in the Hollywood Ten boycott. Despite the oligopolistic structure of the motion picture industry, ${ }^{20}$ the blacklist itself adds nothing to the economic power of the major concerns, since those boycotted are not in competition with the members of the combination. Thus the motion picture industry's distinguishing of the Hollywood blacklist from the boycotts condemned in Fashion Originators' Guild and Klor's is not entirely implausible.

An equally reasonable reading of those two cases, however, suggests the opposite interpretation. Thus, in Fashion Originators Guild, although the Court asserted the presence of a tendency toward monopoly, no attempt was made to support this assertion by economic analysis. Justice Black's enumeration of the factors found in the Fashion Originators' Guild boycott, ${ }^{21}$ moreover, is as consistent with the interpretation that each of them individually would have been sufficient for a finding of illegality, as with the opposite interpretation that all must be present for a boycott to be illegal. Similarly, in Klor's, the reference to "trader" may be taken as including not only a competitor, but anyone within the industry, regardless of his relationship to the boycotters. In fact, while instigated by a competing retailer, the boycott against Klor's was actually conducted by its suppliers. ${ }^{22}$ And the Court's assertion that the

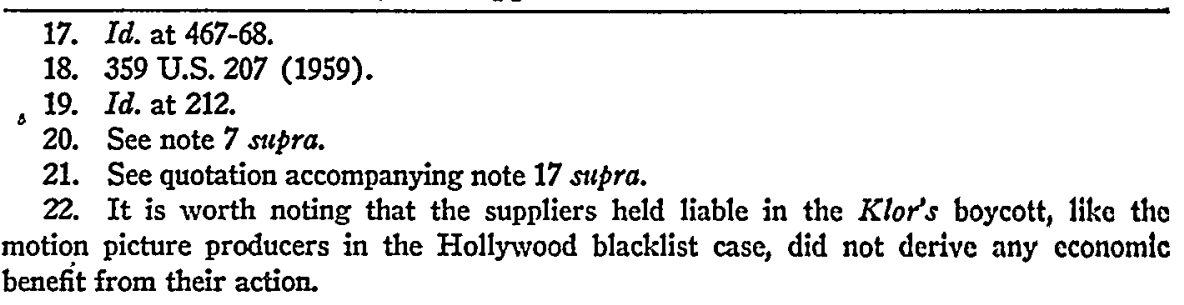


boycott tended toward monopoly ${ }^{23}$ is vitiated by the lower court's finding that the number of appliance dealers in the area had increased since the occurrence of the alleged violation. ${ }^{24}$ The Court actually places less emphasis on the monopolistic tendency of the combination than on its restrictive effect on the freedom of both the victim and the boycotters. ${ }^{20}$

In sum, Fashion Originators' Guild and Klor's are susceptible to divergent interpretations and are thus of limited value in predicting the legality of the Hollywood boycott. Viewed in the context of previous Supreme Court decisions on boycotts, and in the general framework of Sherman Act policy, however, the broader reading of Fashion Originators' Guild and Klor's emerges as the more reasonable one, and the Hollywood blacklist seems clearly illegal.

The earlier boycott cases decided under the Sherman Act, unlike the opinions in Fashion Originators' Guild and Klor's, do not seem to consider the monopolistic effect of a boycott important to its illegality, but emphasize instead the combination itself. In Eastern States Retail Lumber Dealers' Association v. United States, ${ }^{26}$ for example, the Court held illegal a retail-sponsored blacklist of wholesalers who sold directly to the public in competition with local retailers, stressing that such a refusal to deal, though lavful when done by one, is an antitrust violation when done by several acting in concert. As the Court stated in a later case, "the illegality consists, not in the separate action of each, but in the conspiracy and combination of all to prevent any of them from dealing with the [victim]."27 These earlier cases, then, demonstrate a concern more for the restrictive nature of the agreement on the boycotters than for its effect on the victim, and indicate that the boycotts involved were condemned for their use as tools in manipulating the forces of the market,

23. [The boycott] clearly has, by its "nature and character," a "monopolistic tendency." As such it is not to be tolerated merely because the victim is just one merchant whose business is so small that his destruction makes little difference to the economy. Monopoly can as surely thrive by the elimination of such small businessmen, one at a time, as it can by driving them out in large groups. In recognition of this fact the Sherman Act has consistently been read to forbid all contracts and combinations "which "tend to create a monopoly," "whether "the tendency is a creeping one" or "one that proceeds at full gallop."

359 U.S. at 213-14. Accord, Radiant Burners, Inc. v. Peoples Gas Light \& Colse Co., 364 U.S. 656, 660 (1961).

24. Klor's, Inc. จ. Broadway-Hale Stores, Inc, 255 F2d 214, 223-24, 234 (1958).

25. This combination takes from Klor's its freedonn to buy appliances in an open competitive market and drives it out of business as a dealer in the defendants' products. It deprives the nnandacturers and distributors of their frecdont to sell to Klor's at the same prices and conditions made available to Broadway-Hale and in some instances forbids them from selling to it on any terms whatsoever.

359 U.S. at 213 (emphasis added).

26. 234 U.S. 600 (1914).

27. Binderup v. Pathe. Exch., Inc, 263 U.S. 291, 312 (1923). Accord, Paramount Famous Lasky Corp. v. United States, 282 U.S. 30, 41 (1930); United States v. First Nat'l Pictures, Inc., 282 U.S. 44 (1930). 
regardless of whether such manipulation created a monopoly. ${ }^{28}$ As a result, the cases did not confine illegal boycotts to those against competitors. In one case, for example, a large motion picture exhibitor, blacklisted by a Film Board of Trade (whose membership consisted of distributors) for dealing with some of its members and not with others, prevailed on a boycott theory. ${ }^{20}$ Anderson $v$. Shipozeners' Association ${ }^{30}$ is a case even more closely analogous to the Hollywood blacklisting situation, since it involved a combination to control employment. The members of the association agreed to control the terms of employment of all seamen on their vessels, and prevented those senmen who failed to comply from obtaining any employment in the industry. The Court, condemning the boycott because of its restrictive effect on the freedom of shipowners to hire whom they pleased, did not distinguish this boycott from one against competitors. ${ }^{31}$ These earlier cases seem to retain their vitality in light of the fact that the Court in both Fashion Originators' Guild and Klor's cited them with approval, ${ }^{32}$ and did not clearly limit the category of illegal boycotts to those directed against competitors and monopolistic in effect. ${ }^{33}$ Moreover, as recently as 1957, in Radovich v. National Football League, ${ }^{34}$ the Court seemed to assume that a concerted refusal to hire was within the prohibition of the Sherman Act. ${ }^{35}$ From this case and the enrlier boycott cases, it appears that the Hollywood blacklist comes within the putr-

28. Cf. one commentator's suggestion that pressure brought to bear by a concerted refusal to deal, "where it is applied by persons in the same class as the one offended but who themselves have no direct cause of grievance against the offender," is condemncd by the courts as an illegal restraint because "such conduct is not a normal course of events." Kirkpatrick, Commercial Boycotts as Per Se Violations of the Sherman Act, 10 Gro. WASH. L. REv. 302, 309 (1942).

29. Binderup v. Pathe Exch., Inc., 263 U.S. 291 (1923).

30. 272 U.S. 359 (1926).

31. [E] ach shipowner and operator in this widespread combination has surrendered his freedom of action in the matter of employing seamen and agreed to abide by the will of the associations.... These shipowners and operators having thus put themselves into a situation of restraint upon their freedom to carry on interstate and foreign commerce according to their own choice and discretion, it follows . . . that the combination is in violation of the Anti-Trust Act.

272 U.S. at 364-65. But cf. Union Circulation Co. v. FTC, 241 F.2d 652 (2d Cir. 1957).

32. 312 U.S. at 465 (Eastern States); 359 U.S. at 211-12 (Eastern States and Binder$u p \dot{j}$.

33. Contra, Interborough News Co. v. Curtis Publishing Co., 127 F. Supp. 286 (S.D. N.Y. 1954), aff'd, 225 F.2d 289 (2d Cir. 1955), with dictum to the effect that a boycott itself is not condemned, but it is condemned when the purpose or necessary result of concerted action is a tendency toward the creation of a monopoly.

34. 352 U.S. 445 (1957).

35. Radovich, who was blacklisted by a professional football league and thus unable to obtain employment with any affiliated club because he had previously broken a contract with a member club in order to play for a rival football league, alleged that he was damaged as a result of this concerted refusal to hire in violation of the Sherman Act. On a motion to dismiss, the Court held that the complaint stated a good cause of action. 
view of the Sherman Act, despite the fact that its structure is not identical to the boycotts condemned in Fashion Originators' Guild and Klor's.

Support for this proposition can be derived from an analysis of the history of the Sherman Act and the policies Congress and the Courts have sought to promote by it. Although the debates on the Sherman Act were largely concerned with the problem of controlling powerful "trusts,"30 the attempt to confine its scope solely to "trusts" was frustrated shortly after its enactment. ${ }^{37}$ Rather than treating the act as essentially proscriptive, the courts have applied it as a "charter of freedom" 38 to promote and foster competition." Imputing to the framers the fear that those who were to be coerced by the forces of the free market to serve the public would by combination and conspiracy succeed in diverting those forces to their own ends, ${ }^{40}$ the courts have applied the act not only to monopolies but to any practice restraining competition. It is undoubtedly on this basis that boycotts have been consistently condemned. Whether the relationship between the boycotters and their victim is that of competitor, manufacturer-retailer, or employer-employee, the effect is the same: the boycotters have arrogated to themselves the power to decide which services or products the public was to receive. In addition to treating the act as a positive instrument of economic policy, the courts have also attributed to Congress an interest in protecting the individual. The Sherman Act was intended, in the words of one court, to protect "the right of every individual to

36. See 21 CoNG. Rec. 2457-74, 2556-72, 2597-2616, 2639-62, 2901, 3145-53, 4088-4104 (1890).

37. In a case brought only a few years after the passage of the Sherman Act, it was contended by the defendants that the act, being "aimed at monopoly of trade or commerce by which trade should be engrossed, and in and by which property should be employed and secured," was therefore not applicable in the instant case. The court, admitting that the bill, as originally proposed in the Senate, "was directed wholly against trusts," nevertheless concluded that the Sherman Act had a broader applicability. United States v. Debs, 64 Fed. 724, 746-47 (C.C.N.D. Ill. 1894). The Supreme Court upheld the Circuit Court on other grounds, but did not contradict the Circuit Court's views on the scope of the Sherman Act. In re Debs, 158 U.S. 564, 600 (1895). See also Loewe v. Lawlor, 208 U.S. 274 (1908).

38. "As a charter of freedom, the Act has a generality and adaptability comparable to that found to be desirable in constitutional provisicns." Appalachian Coals, Inc. v. United States, 288 U.S. 344, 359-60 (1933). See also 21 CoNG. REc. 2461 (1890) (remarks of Senator Sherman referring to the proposed bill as "a bill of rights, a charter of liberty"). See also Northern Pac. Ry. v. United States, 356 U.S. 1, 4 (1958).

39. Although initially the Sherman Act was utilized as a means of prohibiting the more obvious anti-competitive abuses of the large trusts, it eventually evolved into a means of implementing a particular economic policy.

This change of emphasis from a negative (literally "anti-trust") approach to a positive ("maintaining competition") aim ... has exerted a recognizable influence, particularly in the most recent period, on the development of the case law and the choice of suitable remedies.

Neate, The Antitrust Laws of the Uintted States of Ayterica 29 (1962).

40. It has been aptly stated that a combination constitutes a restraint of trade when it "substituted control of the market for control by the market." Stocknic \& Warkmis, MONOPOLY AND FreE ENTERPRISE 263 (1951). 
choose his own calling in life and to follow the trade of his choice unhampered by any undue and unfair interference from others." 11 This concern undoubtedly derives from common law doctrine which condemned restraints effected by agreements to refrain from practicing a particular trade. ${ }^{42}$ An early Massnchusetts case ${ }^{43}$ indicates the policies upon which these contracts were condemned:

1. Such contracts injure the parties making them, because they diminish their means of procuring livelihoods and a competency for their families....

2. They tend to deprive the public of the services of men in the employ ments and capacities in which they may be most useful to the community as well as themselves.

3. They discourage industry and enterprise, and diminish the products of ingenuity and skill.44

Both the policies embodied in the Sherman Act and its application by the courts therefore support the condemnation of all boycotts regardless of the relationship of the victim to the boycotters. ${ }^{45}$

The motion picture industry argues, however, that even assuming concerted refusals to hire are encompassed by the Sherman Act, the Hollywood blacklist should not be prohibited since its purpose is justifiable. Ostensibly the blacklist was designed to restore the confidence of the public in the industry after the congressional investigations, ${ }^{46}$ though it might also have been motivated in

41. United States v. Motion Picture Patents Co., 225 Fed. 800, 802 (E.D. Pa. 1915).

42. It seems clear that the Sherman Act was intended to incorporate common law dactrine on restraints of trade. See, e.g., 21 Cong. Rec. 2456-61 (1890); Standard Oil Co. v. United States, 221 U.S. 1, 51 (1911). For early condemnation of such agreements, see, e.g., Dyer's Case, Y.B. Pasch. 2 Hen. 5, f. 5, pl. 26 (1415); Tailors of Ipswich, 11 Colie 53a, 77 Eng. Rep. 1218, 1219 (K.B. 1614). Later in the development of the common law certain covenants in restraint of trade - those that were ancillary to the main purpose of a lawful contract - were permitted. See United States v. Addyston Pipe \& Stecl Co., 85 Fed. 271 (6th Cir. 1898).

43. Alger v. Thacher, 36 Mass. (19 Pick.) 51 (1837).

44. Id. at 54 .

45. The [Sherman Act] ... does not confine its protection to consumers, or to purchasers, or to competitors, or to sellers. Nor does it immunize the outlawed acts because they are done by any of these.... The Act is comprehensive in its terms and coverage, protecting all who are made victims of the forbidden practices by whomever they may be perpetrated.

Mandeville Island Farms, Inc. v. American Crystal Sugar Co., 334 U.S. 219, 236 (1948).

46. In Young v. Motion Picture Ass'n, Inc., 28 F.R.D. 2 (D.D.C. 1961), Judga

Walsh, by way of dictum, declared that

... a fuller presentation of the facts in this case may indicate their actions do not constitute a conspiracy to restrain trade in violation of the antitrust laws, but their agreement was reasonable in view of the fact that the confidence of the public in the motion picture industry had been placed in question as a result of the Congressional investigations of the industry .... It may well be that here ... there is a necessity to exhume insofar as possible any taint or stigma of Communist worlemanship on the motion pictures, etc., produced.

Id. at 6 . 
part by a desire to bar Communist propaganda from the screen and to avoid indirect subsidies to subversive organizations. ${ }^{47}$ While these goals may be desirable in themselves, Sherman Act precedent would appear to prohibit their accomplishment by means of a concerted refusal to deal. The Supreme Court, in considering boycotts, has consistently refused to inquire into the reasonableness of their purpose; in short, a per se rule has been established. ${ }^{43}$ In an early Sherman Act decision the Court emphasized that the Sherman Act could not

be evaded by good motives. The law is its own measure of right and wrong, of what it permits, or forbids, and the judgment of the courts cannot be set up against it in a supposed accommodation of its policy with the good intention of parties, and it may be, of some good results.40

And in Fashion Originators' Guild the Court affirmed the refusal of the Federal Trade Commission to hear evidence bearing on defendants' claim of justification, stating that the unlawful combination could not

be justified upon the argument that systematic copying of dress designs is itself tortious ... [for] even if copying were an acknowledged tort under the law of every state, that situation would not justify petitioners in combining together to regulate and restrain interstate commerce in violation of federal law..$^{50}$

An analysis of these cases applying the per se approach indicates that the justifications offered in defense were all couched in terms of economic selfinterest. Several lower courts have apparently read the rejections of these defenses as implicitly approving non-economic justifications of boycotts. 11 Thus in Council of Defense v. International Magasine Co. ${ }^{62}$ the Court of Appeals

47. For further conjecture as to motives, see Horowitz, Legal Aspects of "Political Blacklisting" in the Entertainment Industry, 29 So. CAL. L. Rev. 263, 264 (1956); Scromach, The Face on the Cutring Rooss Floor 123 (1964). See also Coons, Non-Commercial Purpose as a Sherman Act Defense, 56 Nw. U.L. Rev. 705, 754 (1962).

48. Commentators have generally agreed that while some lower courts have attempted to fashion certain justifiable circumstances in which boycotts would not be illegal, the Supreme Court, especially in its Klor's decision, has made it clear that boycotts are illegal per se and cannot be justified. See Handler, Recent Developments in Antilrust Low: 1958-1959, 59 Coluns. L. Rev. 843, 862 (1959); Oppenheim, Selected Antilrust Developments in the Courts and Federal Trade Commission during the Past Ycar, 15 A.B.A. ANTrtrust Section 37, 54 (1959); Loevinger, Rule of Reason in Anti-frust Low, 7 Prac. LAw. 17 (Nov. 1961). See also dicta supporting the doctrine of per se illegality of group boycotts in Northern Pac Ry. v. United States, 356 U.S. 1, 5 (1958); Times-Picayune Publishing Co. v. United States, 345 U.S. 594, 625 (1953); Kiefer-Stewart Co. v. Joscph E. Seagram \& Sons, Inc., 340 U.S. 211, 214 (1948). But see Rahl, Par Se Rules ard Boycotts Usder the Sherman Act: Some Reflections on the Klor's Case, 45 VA. L. REv. 1165 (1959).

49. Standard Sanitary Mfg. Co. v. United States, 226 U.S. 20, 49 (1912), quoted in Paramount Famous Lasky Corp. v. United States, 282 U.S. 30, 44 (1930).

50. 312 U.S. at 468.

51. See, e.g., Hughes Tool Co. v. Notion Picture Ass'n, 66 F. Supp. 1006, 1013 (S.D. N.Y. 1946), discussed in Coons, supra note 47, at 745-46.

52. 267 Fed. 390 (8th Cir. 1920), discussed in Coons, supra note 47, at 742-44. 
for the Eighth Circuit, although holding a boycott by newsdealers of magazines published by the International Magazine Company illegal, indicated in dicta that a non-economic purpose might be a valid defense under other circumstances. The boycott was designed to protect the citizens of New Mexico during World War I from the allegedly un-American and pro-German views of William Randolph Hearst, the magazine company's largest stockholder. Although the court held this particular boycott illegal under the Sherman Act, its emphasis on the failure to show that any of Hearst's objectionable views appeared in the boycotted magazines may imply that a boycott of magazines actually containing those views would have been upheld. More recently, in Molinas v. National Basketball Association ${ }^{63}$ the District Court for the Southern District of New York upheld a concerted refusal to hire a basketball player suspended for having bet on his own team in violation of the association's rule, stating that such restraint was not illegal because "a disciplinary rule invoked against gambling seems about as reasonable a rule as could be imagined." 54

While these lower court cases may be read to support the conclusion that the Supreme Court's per se approach is confined to economic-purpose boycotts, the Supreme Court itself has indicated a contrary understanding. In Silver v. New York Stock Exchange ${ }^{55}$ the respondent Exchange, by joint action of its members, discontinued the private wire connection of petitioner, a non-member security dealer. The Exchange refused to disclose to Silver the reasons for its action, but later revealed in pre-trial hearings that it was motivated at least partially by the suspension of Silver's security clearance by the

53. 190 F. Supp. 241 (S.D.N.Y. 1961).

54. Id. at 244. The Molinas-type boycott - instituted by a sports league or professional association - is in any event distinguishable from the fact situation presented by the Hollywood blacklist. In Molinas, or, for example, in a refusal by the American Medical Association to admit chiropractors to membership, there is a pre-existent, valid joint venture or arrangement, to which the restraint is, in a meaningful sense, ancillary. In the case of the Hollywood blacklist, however, the motion picture producers have come together for only one purpose - the boycott itself. A joint venture has been defined as

a group which undertakes an economically productive activity in concert in order to overcome the impracticability of any one member's amassing sufficient capital for the project or in order to eliminate the economic waste involved in duplication of effort.

Note, Concerted Refusals to Deal Under the Federal Antitrust Lawus, 71 Harv. L, Rev. 1531, 1536 (1958); see KAysen \& TuRNer, ANtitrust Policy 136-41 (1959). It can be argued that a refusal to deal, when incidental to or in furtherance of the valid main purpose of a joint venture, should not be considered, for purposes of the Sherman Act, a group boycott, whose sole purpose or effect is to restrain trade.

One type of group boycott which probably should be outside the scope of the Sherman Act is the consimer boycott, because it presumably reflects the play of market forces which that act meant to preserve. One commentator has attempted to distinguish between consumer boycotts which impose restrictions and those whose ultimate goal is to remove restrictions - Marcus, Civil Rights and the Antitrust Laws, 18 U. Cur. L. REv. 171, 215 (1951) - but this distinction seems tenuous at best.

55. 373 U.S. 341 (1963). 
Department of Defense some six years before. ${ }^{6 B}$ The Supreme Court, however, did not even refer to the purpose, stating that

It is plain ... that removal of the wires by collective action of the Exchange and its members would, had it occurred in a context free from other federal regulation, have constituted a per se violation of Section 1 of the Sherman Act. The concerted action of the Exchange and its members here was, in simple terms, a group boycott depriving petitioners of a valuable business service which they needed in order to compete effectively as broker-dealers in the over-the-counter securities market.

Disposing of the case on grounds of the relationship between the Securities Exchange Act and the Sherman Act, the Court indicated that, absent congressional exemption removing boycotts from the scope of the Sherman Act, ${ }^{\text {ss }}$ all boycotts are illegal per se.

This understanding is consistent with a fundamental tenet of American political and social thought reflected in part in the Sherman Act. ${ }^{\text {to }}$ The fear of concentration of economic power in private hands, enabling a private group to exercise powers comparable to a government without the public responsibility inherent in representative government, has long been a part of American political philosophy and rhetoric. ${ }^{60}$ One of the purposes consistently attributed to the antitrust laws was to retain governing power in the hands of politically responsible persons. ${ }^{61}$ Senator Sherman himself believed that such private concentration of economic power was alien to our democratic constitution and was as much a tyranny as concentration of political power. ${ }^{62}$ Justice Douglas, more than fifty years after the enactment of the Sherman Act, echoed this same sentiment:

[S] ize in steel is the measure of the power of a handful of men over our economy. ... The philosophy of the Sherman Act is that it should

56. 196 F. Supp. 209, 216-17, 226 (1961). The district court pointed out that this suspension was under the Industrial Personnel Security Program later held unlawiul and void by the Supreme Court in Greene v. McElroy, 360 U.S. 474 (1959). 196 F. Supp. at 226.

57. 373 U.S. at 347.

58. See, e.g., 59 Stat. 34 (1945), 15 U.S.C. $§ 1012$ (1958), which specifically excmpts the business of insurance from the scope of the Sherman Act where such business is regulated by state law. Of course, the fact that Congress has passed legislation regulating or penalizing Communists in other areas cannot justify an implication that private concerted action against Communists is exempted thereby from the antitrust laws. "It is a cardinal principle of construction that repeals by implication are not favored." United States v. Borden Co., 308 U.S. 188, 198 (1939).

59. See generally Thorelit, THe Federal ANTrtrust Potrcy (1954).

60. See, e.g., Curti, The Growtr of Amirrican Thought 611 (2d ed. 1951); Adaurs, The Theory of Soctal Revolutrons 208-10 (1913).

61. See, e.g. United States v. Aluminum Co. of America, 148 F.2d 416, 428-29 (1945). "Power to exclude someone from trade, to regulate prices, to determine what shall be produced, is governing power, whether exercised by public officials or by private groups. In a democracy, such powers are entrusted only to elected representatives of the governed ...." Schwartz, The Schreartz Dissent, 1 Antrrkust BuLl. 37, 39 (1955). See Edwards, Big Business and the Policy of Cosrpetimion 1, 2, 4 (1956).

62. See 21 Cong. REC. 2457 (1890) (remarks of Senator Sherman). 
not exist. For all power tends to develop into a government in itself. Power that controls the economy should be in the hands of elected representatives of the people, not in the hands of an industrial oligarchy. Industrial power should be decentralized. It should be scattered into many hands so that the fortunes of the people will not be dependent on the whim or caprice, the political prejudices, the emotional stability of a few selfappointed men. ... That is the philosophy and the command of the Sherman Act. It is founded on the theory of hostility to the concentration in private hands of power so great that only a government of the people should have it. ${ }^{63}$

In the history of Sherman Act adjudication no practice has been more consistently condemned on the basis of this philosophy than concerted refusals to deal. As one court typically stated:

It is not a prerogative of private parties . . . to install themselves as judges and guardians of the public welfare, and to enforce by drastic and restrictive measures their conceptions thus formed. ${ }^{04}$

'Moreover, in Fashion Originators' Guild the Supreme Court suggested that even though the boycott was aimed only at allegedly tortious conduct,

The combination is in reality an extra-governmental agency, which prescribes rules for the regulation and restraint of interstate commerce, and provides extra-judicial tribunals for determination and punishment of violations, and thus "trenches upon the power of the national legislature and violates the statute."65

And it would seem that this hostility to the concentration of economic power in private hands is as applicable to the Hollywood blacklist as to the boycotts generally condemned by the courts. The motion picture producers, in agreeing to bar "subversive" writers and actors from the industry, have not only interfered with the right of an individual to pursue "his own calling," but have also made the decisions, normally left to the consumer, regarding who should be allowed to provide products and services for the public ${ }^{\text {co }}$ and which intellectual and artistic values are to prevail. ${ }^{67}$ While the individual's right to hire the writers and actors he pleases regardless of merit is generally pro-

- "63. United States v. Columbia Steel Co., 334 U.S. 495, 536 (1948) (dissenting opinion) (emphašis added).

64. FTC v. Wallace, 75 F.2d 733, 737 (1935). See also American Medical Ass'n v. United States, 130 F.2d 233, 249 (1942), aff'd, 317 U.S. 519 (1943).

65. 312 U.S. at 465. See also Kirkpatrick, Commercial Boycotts as Pcr Se Violations of the Sherman Act, 10. GEO. WASH. L. REv. 302, 387, 400 (1942).

66. One commentator has analogized a boycott to a "licensing system" imposed by private groups for private purposes. "The boycotting parties determine who shall cnter, who shall remain in, and who shall be excluded from a field of economic activity." Handler, Recent Developments in Antitrust Laze: 1958-1959, 59 CoLurs. L. REv. 843, 864 (1959).

67. Sèe Schuncace, The Face on the Cutring Room Froor 138-40 (1964), for the thesis that one of the results of the blacklist was the stunting of Hollywood's intellectual and artistic growth. It has been suggested that one of the functions of the antitrust laws is to minimize such a possibility. Schwartz, The Schwartz Dissent, 1 Antrnusr Bull. 37, 40 (1955). 
tected, ${ }^{68}$ what may be permissible conduct by one employer cannot be justified when the denial of economic opportunity is the result of concerted industrywide agreement. For absent such agreement the forces of competition would presumably provide a writer or actor whose services were desired by the public with an offer of employment from a producer more strongly profitoriented ${ }^{69}$ It is exactly this interference with market forces which the Sherman Act was intended to prevent. In spite of this philosophy and the courts' general adherence to it through a per se approach to boycotts, the producers claim that an exception should be created when the boycotts involved are aimed at "desirable" moral, political or social goals. But the commitment to a decentralized economic system and the free operation of market forces requires that all such practices be prohibited regardless of purpose. The Sherman Act, moreover, is not an invitation to de novo judgments by courts as to the desirability of the goals sought to be achieved by anticompetitive practices. In a system based on the balancing of powers, it is not for the courts, in interpreting legislation, to revise the congressional judgment by creating exceptions to it on the basis of what is thought to be "desirable" or "undesirable."70 If it is desirable to take the extreme step of excluding disloyal persons from the entire entertainment industry, such exclusion should be accomplished as a result of a politically responsible decision made through the legislative

68. See Comment, Loyalty and Private Employment: The Right of Employers to Discharge Suspected Subversives, 62 YALE L.J. 954 (1953).

69. Evidence that, absent the agreement, some members of the industry would not have refused to employ the blacklisted writers can be found in the existence of the widesprend and complex black market system for obtaining scripts. See Scruvsacr, TuE FAcE 0:3 THE Cutting Roost Floor 130-40 (1964), for a description of the ways in which this black market operates.

A further indication of the restraint imposed by the blacklist on the executives of Metro-Goldwyn-Mayer, who would have acted differently absent such agreement, is found in Cole v. Loew's, Inc, 8 F.R.D. 508 (S.D. Cal. 1948).

Here is an unusual situation, where an employee, who has given satisfaction to his employers - whom they actually want, and whom . . . cvens now they do not wish to let go . . . - a man of this character was suspended and kept without a salary for over a year to satisfy, not a deep conviction of his employers, - but a policy which the employers adopted, along with others in the industry.

8 F.R.D. at 526-27. See also note 4 supra and accompanying text.

The coercive effect of the combination on the individual producer, restraining his freedom of action as to his own employment practices, eliminates any opportunity for the employee to bargain with the producers individually. It would appear that individual $\mathrm{cm}$ ployers could adequately protect their own interests without the necessity of concerted action. For the questions raised as to the desirability (apart from the antitrust laws) of permitting concerted action if it can be shown that there is an "industry" interest rather than, or in addition to, the interests of the individuals in the industry, which can only be protected by combined action, see Horowitz, Legal Aspects of "Political Blacklisting" in the Entertainnent Industry, 29 So. CAL. L. REv. 263, 269-70 \& n.19 (1956).

70. Compare the unhappy experience in the field of labor law, where the courts in the late nineteenth and early twentieth centuries attempted to draw distinctions on an ad hoc case by case basis between acceptable and unacceptable labor practices, thus making law 
process, $^{71}$ and not by ad hoc judicial decisions or by concerted action of private individuals. Only by condemning boycotts regardless of "justifiable" purpose can the courts fulfill their proper function of effectuating the fundamental philosophy incorporated in the broad proscriptions of the Sherman Act the prevention of the existence and use of vast economic power in the hands of private parties.

without sufficient standards or guides for decisions. "[The judges] drew lines on the basis of hunch and prejudice and accordingly they brought chaos to the bargaining process and disrepute to the judicial process." Wellington \& Albert, Statutory Intcrpretation and the Political Process: A Comment on Sinclair v. Atkinson, 72 YALE L.J. 1547, 1554 (1963). See Winter, Collective Bargaining and Competition: The Application of Antitrist Standards to Union Activities, 73 YALE L.J. 14, 30-38 (1963).

71. Of course, serious questions might be raised as to the constitutionality of such a law. 